\title{
PILOT PLANT EXPERIENCE USING STAMPED CHARGING OF PERUVIAN AND IMPORTED COAL BLENDS*
}

\author{
Yoni Abrigo ${ }^{1}$ \\ Jose Martinez ${ }^{2}$ \\ Mariano de Cordova ${ }^{3}$ \\ Jorge Madias ${ }^{4}$
}

\section{Resumo}

A Aceros Arequipa é a maior siderúrgica do Peru. A empresa opera uma planta em Pisco, com uma aciaria para 850.000 t anuais de aço líquido, e uma capacidade de laminação de $1.250 .000 \mathrm{t}$ anuais de produtos longos. Um projeto de integração vertical incluindo coqueria non-recovery, sinterização e alto-forno foi considerado. Como parte do projeto, um forno piloto de coqueificação foi instalado, com o intuito de testar carvões próprios e importados e obter a máxima participação de carvão local nas misturas. Foram testados sez carvões peruanos e antracito. Os carvões importados escolhidos foram três da Colômbia e quatro dos Estados Unidos. Levando em conta as baixas propriedades dos carvões próprios, foi introduzida a estampagem da carga. A máxima participação dos carvões locais, mantendo a qualidade requerida, foi obtida com $80 \%$ de carvão peruano, e $20 \%$ de um carvão columbiano. Pode-se usar até $10 \%$ de antracito, junto a $60 \%$ de carvão peruano e $30 \%$ de carvão colombiano.

Palavras-chave: Forno piloto de coqueificação; Carvões probremente coqueificáveis; Estampagem da carga.

\section{PILOT PLANT EXPERIENCE USING STAMPED CHARGING OF PERUVIAN AND IMPORTED COAL BLENDS}

\section{Abstract}

Corporación Aceros Arequipa is the largest Peruvian steelmaker. The company operates a facility in Pisco, including a meltshop with a capacity of 850.000 tpa of liquid steel, and rolling mills with a capacity of 1.250 .000 tpa of long rolled products. An upstream integration project has been considered, including mini blast furnace, sinter plant and non-recovery coke plant. As part of this project a pilot coke oven was installed and operated. The aim was to test domestic and foreign coals to obtain blends with maximum participation of local coals. Six domestic coal were selected, plus anthracite. As imported coals, three Colombian and four American coals were selected. Taking into account the poor coking properties of domestic coals, stamped charging was adopted. A maximum participation of $80 \%$ domestic coal was obtained in blends with $20 \%$ of a Columbian coal. Anthracite could be used up to $10 \%$ in blends with $60 \%$ domestic coal and $30 \%$ of a Columbian coal

Keywords: Pilot coke oven; Poor coking coal; Stamped coking blend.

1 Metallurgical Engineer, Manager Metallurgy Division, Corporacion Aceros Arequipa, Pisco, Ica, Peru.

2 Mechanical Engineer, Project Engineer, Engineering Departmen, Corporacion Aceros Arequipa, Pisco, Ica, Peru.

3 Mechanical Engineer, Process Engineer, metallon, San Nicolas, Buenos Aires, Argentina.

4 Metallurgical Engineer, Director, metallon, San Nicolas, Bu.enos Aires, Argentina. 


\section{INTRODUÇÃO}

Corporación Aceros Arequipa is the largest Peruvian steelmaker. The company operates a facility in Pisco, $241 \mathrm{~km}$ South from Lima, on the Pacific Ocean, a facility including a meltshop with a capacity of 850.000 tpa of liquid steel, and rolling mills with a capacity of 1.250 .000 tpa of long rolled products: bar, rebar, wire rod and shapes. An upstream integration project has been considered, including mini blast furnace, sinter plant and non-recovery coke plant. As part of this project a pilot coke oven was installed and operated. The aim was to test domestic and foreign coals to obtain blends with maximum participation of local coals. The coke quality aimed for the mini blast furnace was defined elsewhere [1] and is summarized in table 1.

Table 1. Aimed coke quality.

\begin{tabular}{|l|c|c|}
\hline Variable & Unit & Value \\
\hline Micum 40 & $\%$ & $\geq 80$ \\
\hline Micum 10 & $\%$ & $\leq 9$ \\
\hline Ash & $\%$ & $\leq 12$ \\
\hline Sulphur & $\%$ & $\leq 1$ \\
\hline
\end{tabular}

Usually, industrial coke quality lies below the pilot coke oven quality [2]. Nevertheless, in this case the tests were carried out as for a conventional, slot oven byproduct recovery plant, with relatively short coking time. It is expected with the much longer coking time typical of non-recovery coke ovens, a coke quality similar or better than that of the pilot coke oven will be obtained.

This paper includes a short review of Peruvian coal resources, the main features of the domestic and imported coal, a shot description of the equipment used for coal preparation, coking, quenching and testing, as well as a summary of the pilot coke experiences with domestic and imported coals.

In Table 2 and Figure 1, main coal basins in Peru are mentioned, including coal type, reflectivity, FSI and total reserves, according to [3]. Low- and high-volatile coals of Oyon and Jatunhuasi basins are the more interesting for cokemaking. Anthracite may eventually be included in coking blends to adjust coke properties and increase coal to coke yield. In Oyon basin, low-volatile bituminous coals are located in Pampahuay, and have reflectivities of 1.5-2.0. In Jatunhuasi, the thicker seams are present in Celica, Negro Bueno, Cosmos, Isolina, Cachi-Cachi, Llacta and Chaucha [3]. These seams belong to Corporacion Aceros Arequipa.

Previous studies on coking with domestic coals were surveyed [4-9]. They were carried out mostly with $100 \%$ domestic coals, individually or in blends, and in conventional facilities, not using stamped charging or other methods to improve coke quality.

Table 2. Main coal basins in Peru and their characteristics.

\begin{tabular}{|c|c|c|c|c|}
\hline Basin & Coal type & Reflectance & FSI & $\begin{array}{c}\text { Total reserves } \\
(\mathrm{t})\end{array}$ \\
\hline $\begin{array}{ll}\text { Alto } & \text { Chicama } \\
\text { /Santa } & \\
\end{array}$ & Anthracite, Meta-anthracite & $4.11-5.71$ & 0 & $554,474,000$ \\
\hline Oyon & $\begin{array}{c}\text { Anthracite, Semi-anthracite, } \\
\text { Low-volatile bituminous }\end{array}$ & $1.52-5.50$ & $\mathrm{~N} / \mathrm{D}$ & $190,050,000$ \\
\hline Jatunhuasi & $\begin{array}{l}\text { Low-volatile and High-volatile } \\
\text { bituminous }\end{array}$ & $0.57-2.51$ & 1 a 7 & $62,362,150$ \\
\hline
\end{tabular}




\begin{tabular}{|l|c|c|c|c|}
\hline Goyllarisquisga & $\begin{array}{c}\text { Semi-anthracite, Sub- } \\
\text { bituminous }\end{array}$ & N/D & $\begin{array}{c}<2.5- \\
3\end{array}$ & $9,512,500$ \\
\hline Others & Sub-bituminous, Lignite & $0.27-0.63$ & N/D & $287,723,000$ \\
\hline Total & & & & $1,103,634,035$ \\
\hline
\end{tabular}

\section{COAL SELECTION FOR PILOT OVEN TESTING}

Six domestic coals were selected on the base of their FSI, plus anthracite. Five of them belong to Jatunhuasi basin: Negro Bueno, Celica, Cachi-Cachi, Cosmos and Ayhuin; and one to the Oyon basin (Pampahuay). In Table 3, their main properties are summarized. Three Colombian and four American coals were selected to add caking capacity to the blend and mechanical strength to the coke, see Table 4.

Table 3. Main features of the domestic coals selected.

\begin{tabular}{|l|l|l|l|l|l|l|l|}
\hline Code & P1 & P2 & P3 & P4 & P5 & P6 & AN \\
\hline Name & $\begin{array}{l}\text { Negro } \\
\text { Bueno }\end{array}$ & Celica & $\begin{array}{l}\text { Cachi- } \\
\text { Cachi }\end{array}$ & Pampahuay & $\begin{array}{l}\text { Cos } \\
\text { mos }\end{array}$ & $\begin{array}{l}\text { Ayhuin } \\
\text { Anthraci } \\
\text { te }\end{array}$ \\
\hline Volatile matter (\%) & 33.82 & 35.93 & 31.5 & 21.9 & 30.7 & 30.2 & 4.23 \\
\hline Ash (\%) & 7.86 & 16.76 & 13.8 & 9.5 & 9.3 & 20.7 & 9.12 \\
\hline Fixed carbon (\%) & 58.32 & 47.29 & 54.8 & 68.6 & 60.0 & 49.1 & 86.66 \\
\hline Sulphur (\%) & 2.73 & 4.50 & 5.9 & 0.59 & 1.96 & 2.56 & 0.17 \\
\hline FSI & 6.5 & 6.5 & 0 & 0.5 & 2.5 & 1 to 6 & 0 \\
\hline Max fluidity (ddpm) & 63 & 14336 & 0 & & & & 0 \\
\hline Petrography & & & & & & & \\
\hline V4\% & & & 4 & & & & \\
\hline V5 \% & & & 32 & & & & \\
\hline V6 \% & 2.7 & 10.0 & 58 & & & & \\
\hline V7 \% & 24.2 & 22.6 & 8 & & & & \\
\hline V8 \% & 28.3 & 24.6 & & & & & \\
\hline V9 \% & 12.1 & 9.3 & & & & & \\
\hline Ro \% & 0.82 & 0.8 & 0.61 & & & & \\
\hline ASTM Stability (\%) & 33 & 34 & & & & & \\
\hline M40 $\%)$ & 43.5 & 66.9 & Not aggl. & Not aggl. & 57.0 & & \\
\hline M10 $\%)$ & 8.4 & 11.7 & Not aggl. & Not aggl. & 23.7 & & \\
\hline
\end{tabular}

Table 4. Main features of the imported coals selected.

\begin{tabular}{|l|l|l|l|l|l|l|l|}
\hline Code & $\mathbf{C 1}^{1}$ & $\mathbf{C 2}^{2}$ & $\mathbf{C 3}^{\mathbf{3}}$ & $\mathbf{U 1}^{\mathbf{5}}$ & $\mathbf{U 2}^{\mathbf{5}}$ & $\mathbf{U 3}^{\mathbf{5}}$ & $\mathbf{U 4}^{\mathbf{5}}$ \\
\hline Origin & Colombia & Colombia & Colombia & USA & USA & USA & USA \\
\hline Volatile matter (\%) & 23.86 & 25.67 & 20.49 & 28.78 & 21.27 & 27.31 & 31.35 \\
\hline Ash (\%) & 9.55 & 6.55 & 8.15 & 10.29 & 8.88 & 7.75 & 6.04 \\
\hline Fixed carbon (\%) & 66.59 & 67.78 & 71.36 & & 69.85 & & 62.61 \\
\hline Sulphur (\%) & 0.99 & 0.97 & 0.60 & 0.76 & 0.70 & 0.93 & 1.01 \\
\hline FSI & 8.5 & 8 & 8.5 & 7.5 & 9 & 8 & 8.5 \\
\hline Max. fluidity (ddpm) & 268 & & 59 & 10502 & 917 & 1630 & 29880 \\
\hline Petrography & & & & & & & \\
\hline V8\% & 0.6 & & & & & & \\
\hline V9\% & 1.8 & & & 2.2 & & 1.8 & 11.4 \\
\hline V10\% & 10.9 & & & 33.3 & & 14.7 & 23.4 \\
\hline V11\% & 8.5 & & & 30.1 & & 19.6 & 20.2 \\
\hline V12 \% & 16.3 & & & 3.5 & 10.2 & 15.3 & 8.2 \\
\hline V13\% & 12.1 & & 14.1 & 1.4 & 21.9 & 7.3 & \\
\hline V14 \% & 6.6 & & 31.8 & & 17.8 & 2.4 & \\
\hline V15\% & 3.0 & & 20.7 & & 11.6 & & \\
\hline V16\% & 0.6 & & 7.4 & & 4.8 & & \\
\hline
\end{tabular}




\begin{tabular}{|l|l|l|l|l|l|l|l|}
\hline V17\% & & & & & 2.0 & & \\
\hline Ro \% & 1.25 & & 1.48 & & & 1.18 & 1.09 \\
\hline ASTM stability (\%) & 53.5 & & 61 & 59 & 60 & 61.0 & 59 \\
\hline M40\% & 78.1 & 85.3 & 87.9 & 87.7 & 87.4 & 83.7 & 78.4 \\
\hline M10\% & 7.2 & 6.1 & 6 & 5.1 & 5.9 & 5.4 & 6.7 \\
\hline
\end{tabular}

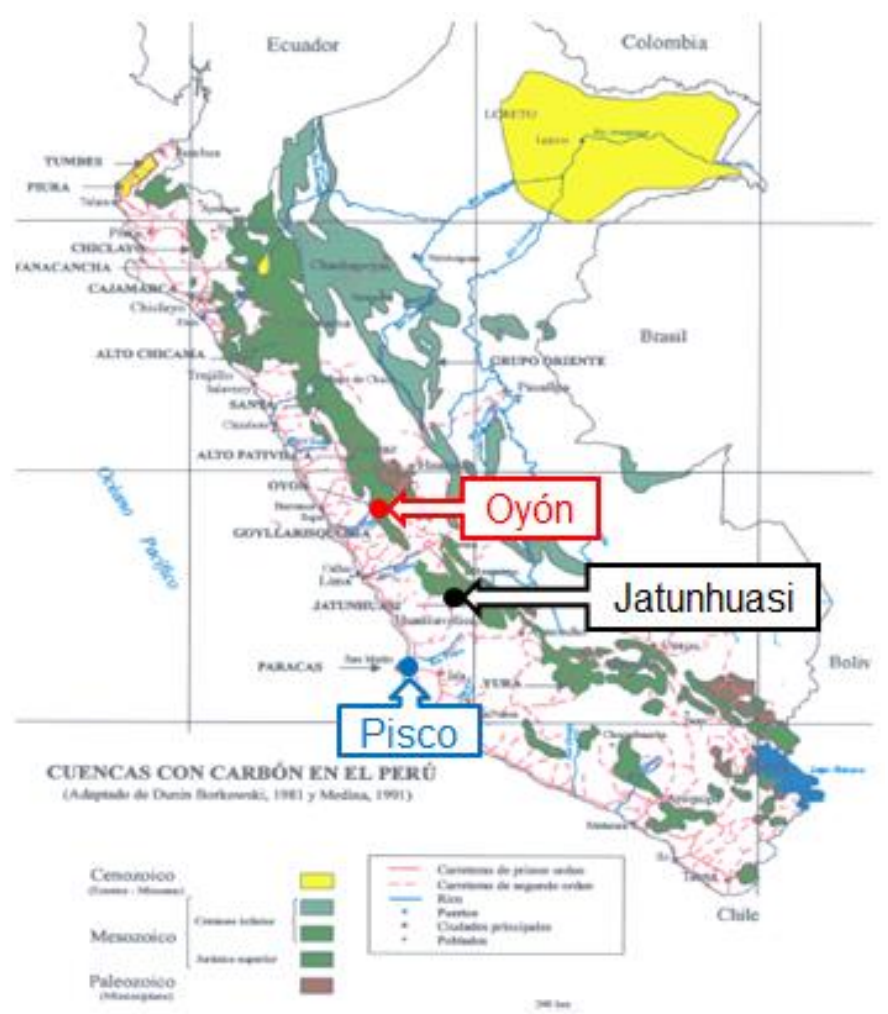

Figure 1. Localization of the Jatunhuasi basins (owned by Corporacion Aceros Arequipa), Oyon basin, and the steel plant in Pisco.

\section{TESTING FACILITIES}

Taking into account the poor coking properties of the selected domestic coals, in order to maximize their participation in the blends, the stamped charging system was selected. As is widely known, this process makes possible to obtain a coal cake with high density (up to $1080 \mathrm{~kg} / \mathrm{dm}^{3}$, dry base), as long as an optimum moisture content is present in the blend (around 10\%). The strength of the coke obtained is higher, as coke porosity decreases and mean thickness of the coke cell walls increases, due to more contact between coal particles [10]. As a result, this technique allows for a higher percentage of poorly coking coals in the blend, in comparison with usual lowdensity charge. A pilot oven scale of $40 \mathrm{~kg}$ was chosen, taken into account the easy of use of this size, and the coke needed for testing.

Domestic coals were washed to reduce ash and sulphur. To this purpose, concentration by dense media according to washability ASTM D 43771 standard, floatation cell Denver D12, Humphrey spiral and column cell were used, after design and built by CAASA.

All coals were ground to $90 \%<2.8 \mathrm{~mm}$ in a lab mill. Anthracite, instead, was ground to $100 \%<1 \mathrm{~mm}$. Coals dosing was carried out with a $100 \mathrm{~kg}$ scale. Mixing was manual. The required water was incorporated with manual spray, to increase moisture from $2 \%$ (due to the particularly dry conditions at the plant) to $10-11 \%$. The $43-50 \mathrm{~kg}$ coal cake was prepared in the stamp equipment, introducing the coal in 
a steel charging box (350 mm wide, $460 \mathrm{~mm}$ length, $460 \mathrm{~mm}$ high) and compacting in four steps (10 strokes in $15 \mathrm{~s}$ each), Figure 2.

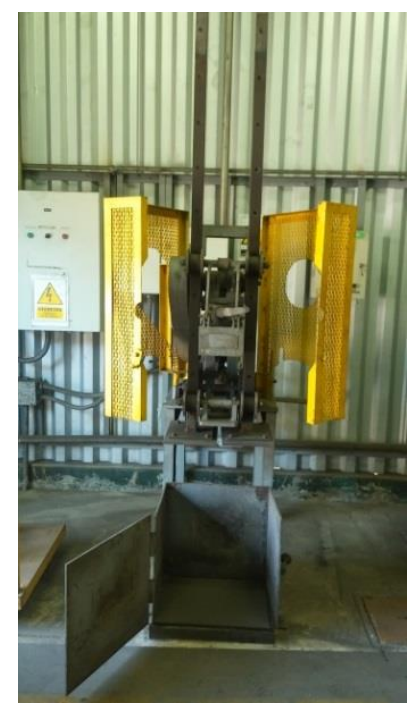

Figure 2. Stamping equipment.

Oven inner dimensions are $400 \mathrm{~mm}$ wide, $500 \mathrm{~mm}$ length and $660 \mathrm{~mm}$ high. Charging is through the bottom, by means of a hydraulic lifting car, see Figure 3.
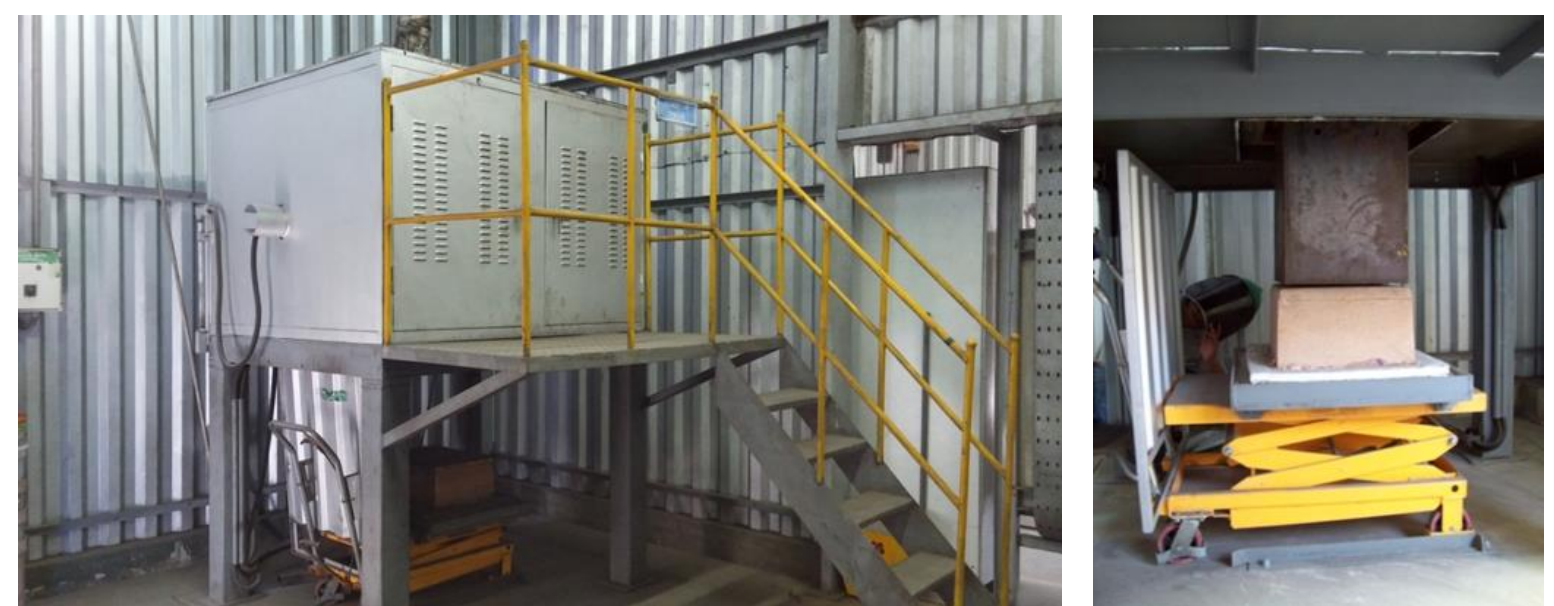

Figure 3. Left: General aspect of the pilot coke oven. Right: Charging of the coal cake in a box through the bottom of the oven, using a hydraulic lifting car.

The oven has two heating walls, each one with six silicon carbide bars, the temperature being measured with a thermocouple in each wall. Coking time may be varied between 14 and 24 hours, but the standard chosen was $18 \mathrm{~h}$. Programmed heating curve is shown in figure 4. 


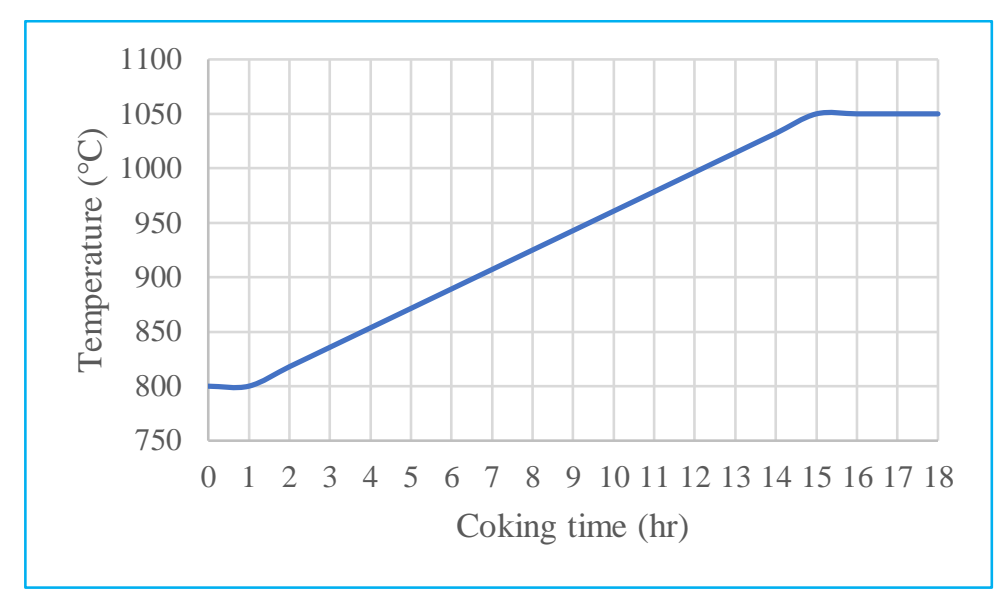

Figure 4. Programmed heating curve for the walls of the pilot coke oven.

Temperature in the center of the charge is taken with a thermocouple, too. It is inserted in the cake after charging, then removed before discharging. The error margin for wall temperature is $\pm 80^{\circ} \mathrm{C}$ and the difference between both walls must be less than $10^{\circ} \mathrm{C}$. The incandescent coke, still within the steel box, is quenched in a quenching tower with water sprays during two minutes, then dumped into a pan and quenched again (figure 5).
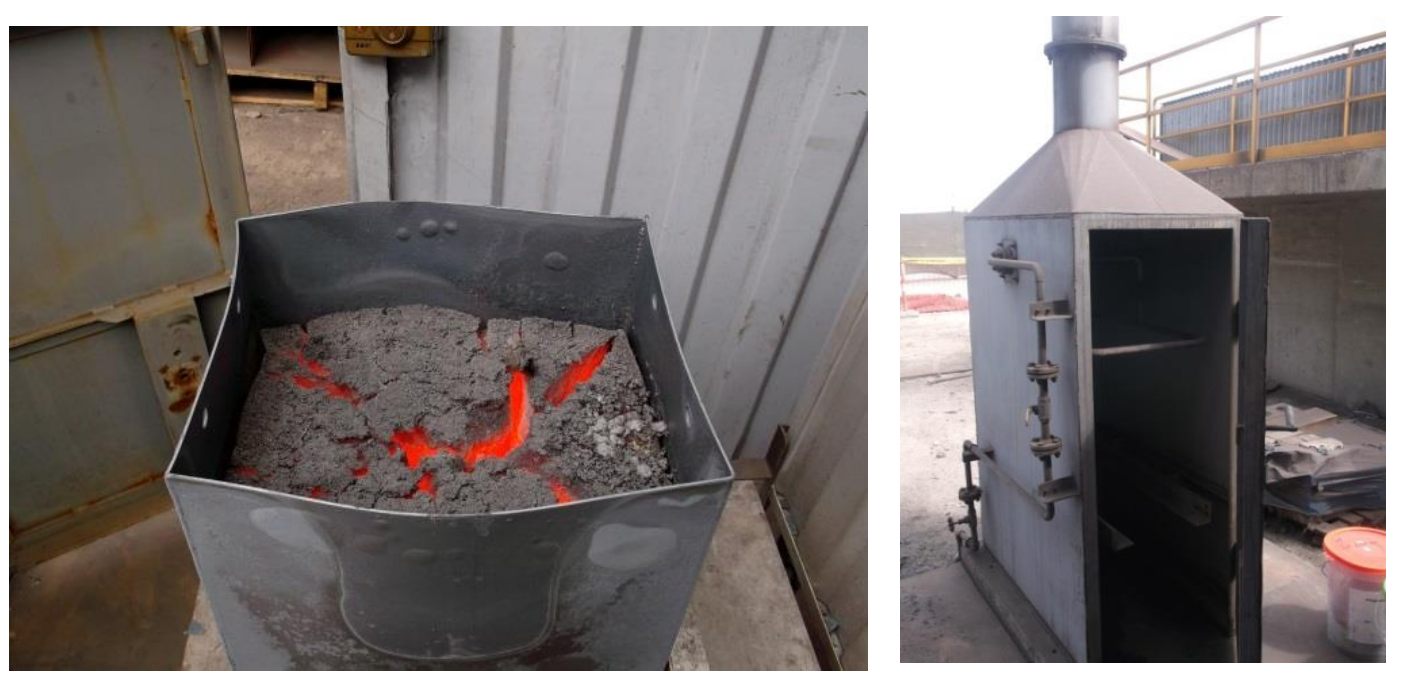

Figure 5. Steel box with incandescent coke after discharge from the oven. Right: quenching tower.

The mechanical testing of the coke was carried out with a shatter test as a first step, for drop strength and coke stabilization. The coke produced, charged in a pan, is let to fall twice from $1.83 \mathrm{~m}$ high. Then it is classified in fractions of $+80 \mathrm{~mm} \varnothing,+60 \mathrm{~mm}$ $\Phi,+40 \mathrm{~mm} \varnothing,+25 \mathrm{~mm} \varnothing,+10 \mathrm{~mm} \varnothing$ and $-10 \mathrm{~mm} \varnothing$, see figure 6 (left). A $1 / 4 \mathrm{MICUM}$ tumbler test was implemented for resistance to fissuring (M40) and to abrasion (M10), according to Chinese GB2006-80 standard: $1000 \mathrm{~mm}$ diameter $250 \mathrm{~mm}$ length. $12.5 \mathrm{~kg}$ of coke of $>80 \mathrm{~mm}$ and $80-60 \mathrm{~mm}$ are charged and the tumbler rotates 100 turns to 25 rpm (figure 6, right). 

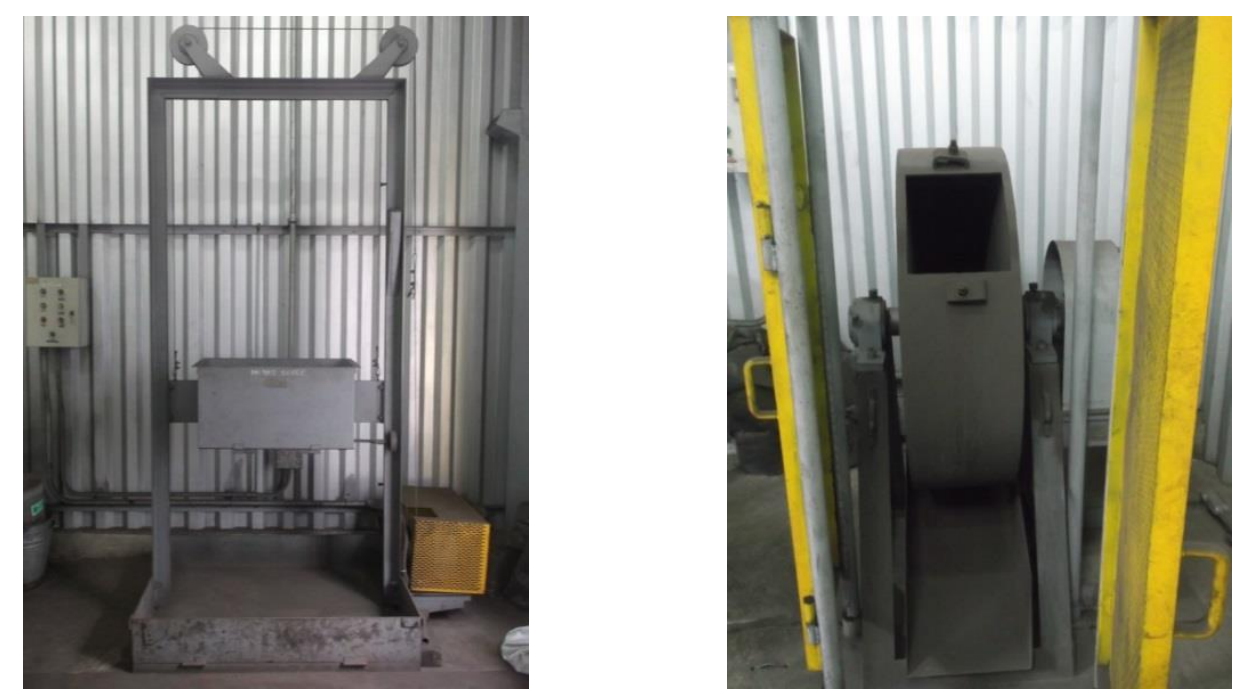

Figure 6. Equipment for shatter test (left) and $1 \frac{1}{4}$ MICUM test (right).

\section{COKING TESTS AND RESULTS}

Taking into account the above mentioned characterization data and coke quality requirements, different blends were formulated, for extensive testing. The blends included domestic coals washed and not washed, disaggregating coals P1 and P2 in seams A, B, and C with Colombian coals C2 and C3 and American coal U1. Priority was given to tests of coals P1 and P2, seam B, because of their high FSI compared with other local coals. Anthracite was then included in blends with domestic coals P1 and P2, Colombian coal C2 and American coal U2. As pressure on oven walls is not a concern for non-recovery horizontal coke ovens, there was no limits to the participation in the blends of low-volatile Colombian coal C3. In table 5 the main blends tested are presented.

Table 5. Blends tested in the pilot coke oven.

\begin{tabular}{|c|c|c|c|c|c|c|c|c|c|c|c|c|c|}
\hline \multirow[t]{2}{*}{$\begin{array}{l}\text { TEST } \\
\text { NUMBER }\end{array}$} & \multicolumn{9}{|c|}{ DOMESTIC COALS } & \multicolumn{4}{|c|}{$\begin{array}{l}\text { IMPORTED } \\
\text { COALS }\end{array}$} \\
\hline & P1 & P2 & P1W & P2W & P5 & P5W & P6 & P6W & Anthracite & $\mathrm{C} 2$ & C3 & U1 & $\mathrm{U} 2$ \\
\hline 5 & 0 & & & & & & & & & & 100 & & \\
\hline 8 & B50 & & & & & & & & & & 50 & & \\
\hline 9 & $\mathrm{~B} 30$ & & & & & & & & & & 70 & & \\
\hline 11 & B100 & & & & & & & & & & 0 & & \\
\hline 13 & B70 & & & & & & & & & & 30 & & \\
\hline 14 & & B100 & & & & & & & & & 0 & & \\
\hline 15 & & B90 & & & & & & & & & 10 & & \\
\hline 16 & & B80 & & & & & & & & & 20 & & \\
\hline 17 & & B70 & & & & & & & & & 30 & & \\
\hline 18 & & $\mathrm{~B} 60$ & & & & & & & & & 40 & & \\
\hline 19 & & B50 & & & & & & & & & 50 & & \\
\hline 20 & & $\mathrm{~B} 40$ & & & & & & & & & 60 & & \\
\hline 21 & & B30 & & & & & & & & & 70 & & \\
\hline 29 & & & B100 & & & & & & & & 0 & & \\
\hline 30 & & & B90 & & & & & & & & 10 & & \\
\hline 31 & & & B80 & & & & & & & & 20 & & \\
\hline 32 & & & B70 & & & & & & & & 30 & & \\
\hline 33 & & & & B100 & & & & & & & 0 & & \\
\hline 34 & & & & B90 & & & & & & & 10 & & \\
\hline
\end{tabular}




\begin{tabular}{|c|c|c|c|c|c|c|c|c|c|c|c|c|}
\hline 35 & & & & B80 & & & & & & & 20 & \\
\hline 36 & & & & B70 & & & & & & & 30 & \\
\hline 40 & & & & & & 100 & & & & & 0 & \\
\hline 41 & & & & & 50 & & & & & & 50 & \\
\hline 42 & & & & & 30 & & & & & & 70 & \\
\hline 43 & & & & & & 50 & & & & & 50 & \\
\hline 44 & & & & & & 30 & & & & & 70 & \\
\hline 45 & & & & & & & 50 & & & & 50 & \\
\hline 46 & & & & & & & 30 & & & & 70 & \\
\hline 47 & & & & & & & & 50 & & & 50 & \\
\hline 48 & & & & & & & & 30 & & & 70 & \\
\hline 54 & C70 & & & & & & & & & & 30 & \\
\hline 55 & & A70 & & & & & & & & & 30 & \\
\hline 56 & & & C80 & & & & & & & & & 20 \\
\hline 57 & & & A80 & & & & & & & & & 20 \\
\hline 58 & & & B80 & & & & & & & & & 20 \\
\hline 59 & & & & A80 & & & & & & & & 20 \\
\hline 61 & & & & B80 & & & & & & & & 20 \\
\hline 62 & & & & C80 & & & & & & & & 20 \\
\hline 63 & & & & C80 & & & & & & 20 & & \\
\hline 64 & & & C80 & & & & & & & 20 & & \\
\hline 65 & & & B80 & & & & & & & & & 20 \\
\hline 66 & & & & B80 & & & & & & & & 20 \\
\hline 67 & & & A55 & B25 & & & & & & 20 & & \\
\hline 68 & & & A50 & B20 & & & & & & 30 & & \\
\hline 73 & & & & A60 & & & & & 10 & 30 & & \\
\hline 74 & & & & A60 & & & & & 20 & 20 & & \\
\hline 78 & & & B50 & & & & & & 20 & & & \\
\hline
\end{tabular}

P1, P2, P5 and P6: not washed domestic coals. P2W, P5W and P6W: washed domestic coals. A, B, C: different seams of coals $P 1$ and $P 2$.

In the following, the results of the tests are discussed ordered by domestic coal type. M40, M10, average coke size and fraction below $25 \mathrm{~mm}$ (nut coke plus coke fines) are included.

Negro Bueno coal (P1). With $30 \%$ of not-washed seam B (P1B), and $70 \%$ of Colombian C3 coal aimed quality was achieved (test 9). After washing, the share of P1BW could be increase to $80 \%$ without missing the aim (test 31 ), see table 6 . The washing not only decreased ash and sulphur but was also helpful in improving M40 and M10.

Table 6. Tests with Negro Bueno coal, non-washed (top) and washed (bottom).

\begin{tabular}{|c|c|c|c|c|c|c|c|c|c|c|c|c|}
\hline $\begin{array}{c}\text { Test } \\
\mathbf{N}^{\circ}\end{array}$ & $\begin{array}{c}\text { P1B } \\
\%\end{array}$ & \multicolumn{4}{|c|}{ P1B/C3 blend } & \multicolumn{6}{c|}{ Coke } \\
\cline { 3 - 15 } & & Moisture & VM & Ash & Sulphur & VM & Ash & Sulphur & M40 & M10 & $\begin{array}{c}\text { Size } \\
\text { (ave.) }\end{array}$ & $\begin{array}{c}<25 \\
\text { mm }\end{array}$ \\
\hline 11 & 100 & 10.4 & 31.9 & 7.6 & 2.65 & 2.0 & 15.6 & 2.26 & 50.4 & 9.0 & 60 & 13.4 \\
\hline 13 & 70 & 9.6 & 27.9 & 8.6 & 1.78 & 1.9 & 17.6 & 1.45 & 78.1 & 11.0 & 68 & 15.9 \\
\hline 8 & 50 & 10.3 & 25.6 & 7.5 & 1.35 & 1.3 & 13.6 & 1.04 & 88.9 & 6.6 & 70 & 8.4 \\
\hline $\mathbf{9}$ & $\mathbf{3 0}$ & $\mathbf{9 . 8}$ & $\mathbf{2 2 . 3}$ & $\mathbf{6 . 8}$ & $\mathbf{1 . 1 0}$ & $\mathbf{1 . 3}$ & $\mathbf{1 2 . 2}$ & $\mathbf{0 . 8 6}$ & $\mathbf{8 5 . 4}$ & $\mathbf{6 . 7}$ & $\mathbf{7 5}$ & $\mathbf{5 . 9}$ \\
\hline 5 & 0 & 10.2 & 18.4 & 8.8 & 0.55 & 2.1 & 13.4 & 0.4 & 88.2 & 5.3 & 74 & 7.4 \\
\hline
\end{tabular}

\begin{tabular}{|c|c|c|c|c|c|c|c|c|c|c|c|c|}
\hline \multirow{2}{*}{$\begin{array}{c}\text { Test } \\
\mathbf{N}^{\circ}\end{array}$} & \multirow{2}{*}{$\begin{array}{c}\text { P1BW } \\
\%\end{array}$} & \multicolumn{4}{|c|}{ P1BW/C3 blend } & \multicolumn{7}{|c|}{ Coke } \\
\hline & & Moisture & VM & Ash & Sulphur & VM & Ash & Sulphur & M40 & M10 & $\begin{array}{c}\text { Size } \\
\text { (ave.) }\end{array}$ & $\begin{array}{l}<25 \\
\mathrm{~mm}\end{array}$ \\
\hline
\end{tabular}




\begin{tabular}{|l|c|c|c|c|c|c|c|c|c|c|c|c|}
\hline 29 & 100 & 11.0 & 33.4 & 4.3 & 1.04 & 1.4 & 7.3 & 0.93 & 49.4 & 8.3 & 62 & 6.8 \\
\hline 30 & 90 & 10.4 & 31.5 & 6.9 & 1.05 & 1.2 & 10.7 & 0.91 & 64.3 & 7.4 & 68 & 5.2 \\
\hline $\mathbf{3 1}$ & $\mathbf{8 0}$ & $\mathbf{1 0 . 6}$ & $\mathbf{3 0 . 4}$ & $\mathbf{6 . 6}$ & $\mathbf{1 . 1 1}$ & $\mathbf{1 . 3}$ & $\mathbf{9 . 5}$ & $\mathbf{0 . 9 2}$ & $\mathbf{8 2 . 2}$ & $\mathbf{6 . 2}$ & $\mathbf{7 1}$ & $\mathbf{5 . 2}$ \\
\hline 32 & 70 & 11.0 & 28.3 & 9.2 & 0.98 & 1.7 & 12 & 0.98 & 89.0 & 5.6 & $\mathbf{7 4}$ & 6.3 \\
\hline
\end{tabular}

Celica coal (P2). Blends of non-washed coal (P2B) and Colombian coal C3 did not reach the aim. Washed coal was successful: the aim is obtained even with $80 \%$ of P2BW and $20 \%$ of C3 (test 35), see Table 7. Again, washing added cost but made feasible a blend with high proportion of domestic coal.

Table 7. Tests with Celica coal, non-washed (top) and washed (bottom).

\begin{tabular}{|c|c|c|c|c|c|c|c|c|c|c|c|c|}
\hline $\begin{array}{c}\text { Test } \\
\mathbf{N}^{\circ}\end{array}$ & $\begin{array}{c}\text { P2B } \\
\%\end{array}$ & \multicolumn{3}{|c|}{ P2B/C3 blend } & \multicolumn{6}{c|}{ Coke } \\
\cline { 3 - 15 } & & Moisture & VM & Ash & Sulphur & VM & Ash & Sulphur & M40 & M10 & $\begin{array}{c}\text { Size } \\
\text { (ave. })\end{array}$ & $\begin{array}{c}<25 \\
\text { mm }\end{array}$ \\
\hline 14 & 100 & 10.0 & 35.4 & 12.5 & 4.41 & 2.4 & 20.9 & 3.67 & 66.9 & 11.7 & 70 & 8.3 \\
\hline 15 & 90 & 10.4 & 33.3 & 12.4 & 4.40 & 2.3 & 20.4 & 3.78 & 73.0 & 10.9 & 73 & 9.4 \\
\hline 16 & 80 & 10.2 & 32.1 & 11.5 & 4.00 & 1.8 & 16.4 & 3.33 & 78.7 & 8.8 & 70 & 4.4 \\
\hline 17 & 70 & 10.2 & 29.7 & 11.0 & 3.35 & 2.0 & 16.7 & 2.48 & 83.5 & 7.5 & 76 & 5.0 \\
\hline 18 & 60 & 10.8 & 28.5 & 10.6 & 3.06 & 2.0 & 16.9 & 2.30 & 86.7 & 6.1 & 73 & 5.2 \\
\hline 19 & 50 & 10.2 & 26.7 & 14.0 & 1.71 & 0.7 & 20.0 & 1.32 & 85.8 & 6.9 & 79 & 4.1 \\
\hline 20 & 40 & 9.7 & 25.0 & 12.3 & 1.97 & 1.4 & 16.9 & 1.51 & 89.4 & 5.9 & 78 & 4.0 \\
\hline 21 & 30 & 10.5 & 23.3 & 11.7 & 1.44 & 0.9 & 17.4 & 1.11 & 87.7 & 6.4 & 80 & 4.5 \\
\hline 5 & 0 & 10.2 & 18.4 & 8.8 & 0.55 & 2.1 & 13.4 & 0.40 & 88.2 & 5.3 & 74 & 7.4 \\
\hline
\end{tabular}

\begin{tabular}{|c|c|c|c|c|c|c|c|c|c|c|c|c|}
\hline $\begin{array}{c}\text { Test } \\
\mathbf{N}^{\circ}\end{array}$ & $\begin{array}{c}\text { P2BW } \\
\%\end{array}$ & \multicolumn{3}{|c|}{ P2BW/C3 blend } & \multicolumn{6}{c|}{ Coke } \\
\cline { 3 - 15 } & Moisture & VM & Ash & Sulphur & VM & Ash & Sulphur & M40 & M10 & $\begin{array}{c}\text { Size } \\
\text { (ave. })\end{array}$ & $\begin{array}{c}<25 \\
\text { mm }\end{array}$ \\
\hline 33 & 100 & 11.6 & 32.5 & 5.2 & 1.51 & 1.5 & 10.2 & 1.22 & 66.6 & 7.7 & 66 & 5.8 \\
\hline 34 & 90 & 11.1 & 32.0 & 8.0 & 1.47 & 1.6 & 12.5 & 1.10 & 74.7 & 6.6 & 73 & 4.9 \\
\hline 35 & $\mathbf{8 0}$ & $\mathbf{1 0 . 2}$ & $\mathbf{3 0 . 6}$ & $\mathbf{6 . 0}$ & $\mathbf{1 . 2 7}$ & $\mathbf{1 . 5}$ & $\mathbf{9 . 8}$ & $\mathbf{1 . 0 2}$ & $\mathbf{8 2 . 4}$ & $\mathbf{7 . 2}$ & $\mathbf{7 2}$ & $\mathbf{5 . 0}$ \\
\hline 36 & 70 & 11.3 & 29.0 & 7.6 & 1.29 & 1.4 & 11 & 1.02 & 85.6 & 6.6 & 72 & 9.9 \\
\hline
\end{tabular}

Cosmos coal (P5). With non-washed coal the quality aim was not achieved. Tests with washed coal were successful. Maximum acceptable was a blend of $30 \%$ washed coal (P5W) and 70\% Colombian coal C3 (test 44), see Table 8.

Table 8. Tests with washed Cosmos coal.

\begin{tabular}{|c|c|c|c|c|c|c|c|c|c|c|c|c|}
\hline Test $\begin{array}{c}\text { Test } \\
\mathbf{N}^{\circ}\end{array}$ & $\begin{array}{c}\text { P5W } \\
\%\end{array}$ & \multicolumn{4}{|c|}{ P5W/C3 blend } & \multicolumn{6}{|c|}{ Coke } \\
\cline { 3 - 15 } & Moisture & VM & Ash & Sulphur & VM & Ash & Sulphur & M40 & M10 & $\begin{array}{c}\text { Size } \\
\text { (ave.) }\end{array}$ & $\begin{array}{c}<25 \\
\mathrm{~mm}\end{array}$ \\
\hline 40 & 100 & 10.8 & 30.7 & 9.3 & 1.97 & 2.5 & 15.4 & 1.71 & 57.0 & 23.7 & 72 & 39.4 \\
\hline 43 & 50 & 10.0 & 24.9 & 8.2 & 1.19 & 1.9 & 16.3 & 0.90 & 68.8 & 19.8 & 65 & 33.8 \\
\hline $\mathbf{4 4}$ & $\mathbf{3 0}$ & $\mathbf{1 1 . 0}$ & $\mathbf{2 2 . 7}$ & $\mathbf{7 . 5}$ & $\mathbf{0 . 9 0}$ & $\mathbf{1 . 0}$ & $\mathbf{1 1 . 4}$ & $\mathbf{0 . 7 1}$ & $\mathbf{8 2 . 7}$ & $\mathbf{7 . 2}$ & $\mathbf{6 9}$ & $\mathbf{1 1 . 1}$ \\
\hline
\end{tabular}

Ayhuin coal (P6). Neither non-washed nor washed blends with this coal, in blends with Colombian coal C3, reached the proposed quality level, due to the high ash content, even in the washed condition, see Table 9.

Table 9. Tests with washed and non-washed Ayhuin coal.

\begin{tabular}{|c|c|c|c|c|c|c|c|c|c|c|c|c|}
\hline $\begin{array}{c}\text { Test } \\
\mathbf{N}^{\circ}\end{array}$ & $\begin{array}{c}\text { P6 } \\
\%\end{array}$ & \multicolumn{3}{|c|}{ P6-P6W/C3 blends } & \multicolumn{6}{c|}{ Coke } \\
\cline { 3 - 15 } & $\begin{array}{c}\text { Moisture } \\
\%\end{array}$ & $\begin{array}{c}\text { VM } \\
\%\end{array}$ & $\begin{array}{c}\text { Ash } \\
\%\end{array}$ & $\begin{array}{c}\text { Sulphur } \\
\%\end{array}$ & $\begin{array}{c}\text { VM } \\
\%\end{array}$ & Ash & Sulphur & M40 & M10 & $\begin{array}{c}\text { Size } \\
(\text { ave. })\end{array}$ & $\begin{array}{c}<25 \\
\text { mm }\end{array}$ \\
\hline 45 & $50 \mathrm{P} 6$ & 9.5 & 23.9 & 17.4 & 1.65 & 1.0 & 23.5 & 1.25 & 81.3 & 11.5 & 80 & 9.7 \\
\hline
\end{tabular}




\begin{tabular}{|c|c|c|c|c|c|c|c|c|c|c|c|c|}
\hline 46 & 30P6 & 10.5 & 22.3 & 13.0 & 1.08 & 1.0 & 19.0 & 0.85 & 88.2 & 6.6 & 68 & 14.7 \\
\hline 47 & 50P6L & 13.7 & 25.4 & 11.2 & 1.05 & 1.3 & 16.4 & 0.8 & 83.5 & 7.0 & 71 & 8.8 \\
\hline 48 & 30P6L & 10.5 & 22.8 & 9.4 & 0.87 & 1.3 & 13.6 & 0.72 & 87.2 & 5.8 & 70 & 12.0 \\
\hline
\end{tabular}

Anthracite. Interestingly enough, with washed $60 \%$ Celica coal, seam B (P2BL), $30 \%$ Colombian coal C2 and 10\% anthracite (test 73 ), the aimed quality is achieved, see table 10. Colombian coal C3 was not used due to lack of stock; may be with it results would be even better, see Table 10.

Table 10. Tests of blends including anthracite.

\begin{tabular}{|c|c|c|c|c|c|c|c|c|c|c|c|c|}
\hline Test & Anthracite & \multicolumn{4}{|c|}{ Blend } & \multicolumn{7}{|c|}{ Coke } \\
\hline $\mathrm{N}^{\circ}$ & $\%$ & $\begin{array}{c}\text { Moisture } \\
(\%)\end{array}$ & $\begin{array}{l}\text { VM } \\
(\%)\end{array}$ & $\begin{array}{l}\text { Ash } \\
(\%)\end{array}$ & $\begin{array}{l}\text { Sulphur } \\
(\%)\end{array}$ & $\begin{array}{l}\text { VM } \\
(\%)\end{array}$ & $\begin{array}{l}\text { Ash } \\
(\%)\end{array}$ & $\begin{array}{l}\text { Sulphur } \\
(\%)\end{array}$ & $\begin{array}{c}\text { M40 } \\
(\%)\end{array}$ & $\begin{array}{l}\text { M10 } \\
\%\end{array}$ & $\begin{array}{l}\text { Size } \\
\text { (avg) }\end{array}$ & $\begin{array}{l}<25 \\
\mathrm{~mm}\end{array}$ \\
\hline $72^{1}$ & 10 & 10.5 & 26.7 & 9.8 & 1.27 & 1.5 & 16.3 & 0.97 & 73.0 & 17.0 & 81 & 8.4 \\
\hline $73^{2}$ & 10 & 9.7 & 26.1 & 9.1 & 1.22 & 0.9 & 11.5 & 0.98 & 86.0 & 8.0 & 80 & 3.3 \\
\hline $74^{3}$ & 20 & 9.3 & 24.4 & 10.0 & 1.31 & 2.0 & 12.8 & 1.04 & 70.0 & 27.0 & 82 & 25.9 \\
\hline $78^{4}$ & 20 & 10.5 & 22.3 & 7.6 & 1.13 & 1.6 & 10.4 & 0.94 & 72.3 & 25.8 & 87 & 12.0 \\
\hline
\end{tabular}

\section{DISCUSSION OF RESULTS}

For this analysis, the model developed at CRM, Liege, Belgium, is applied. This model predicts M40 and M10 based on the Reactive Caking Index (RCI), the Total Inerts Content (TIC) and the maximum fluidity of the blend. Details are presented elsewhere [11]. The results obtained are shown in Figures 7 for blends of washed Negro Bueno coal (seam B) and Colombian coal C3, and in Figure 8 for washed Celica coal (seam B) and Colombian coal C3. For Negro Bueno coal, the calculation is less sensitive to the addition of Colombian coal than the test results

The average coke size for blends of washed Negro Bueno (seam B) and washed Celica coal (seam B) with $20 \%$ of Colombian coal C3 is 71 and $72 \mathrm{~mm}$, respectively. This value is high but adjustable to normal values by means of coke crushing, as usual. The fraction of less than $25 \mathrm{~mm}$ is $5 \%$, which is good. A higher value is to be expected in case of crushing.

It is worth to mention that the addition of $10 \%$ anthracite to the blend with $60 \%$ washed Negro Bueno coal and 30\% Colombian coal C2, allows for an increase in total coke yield from $72 \%$ to $74 \%$, taking test 36 in table 7 as a reference. Sulphur in coke decreases from $1.02 \%$ to $0.98 \%$. Average coke size increases from 72 to 80 $\mathrm{mm}$, as is normal with the addition of inerts to the blend. Besides, fraction with less than $25 \mathrm{~mm}$ is kept low (3.3\%). 

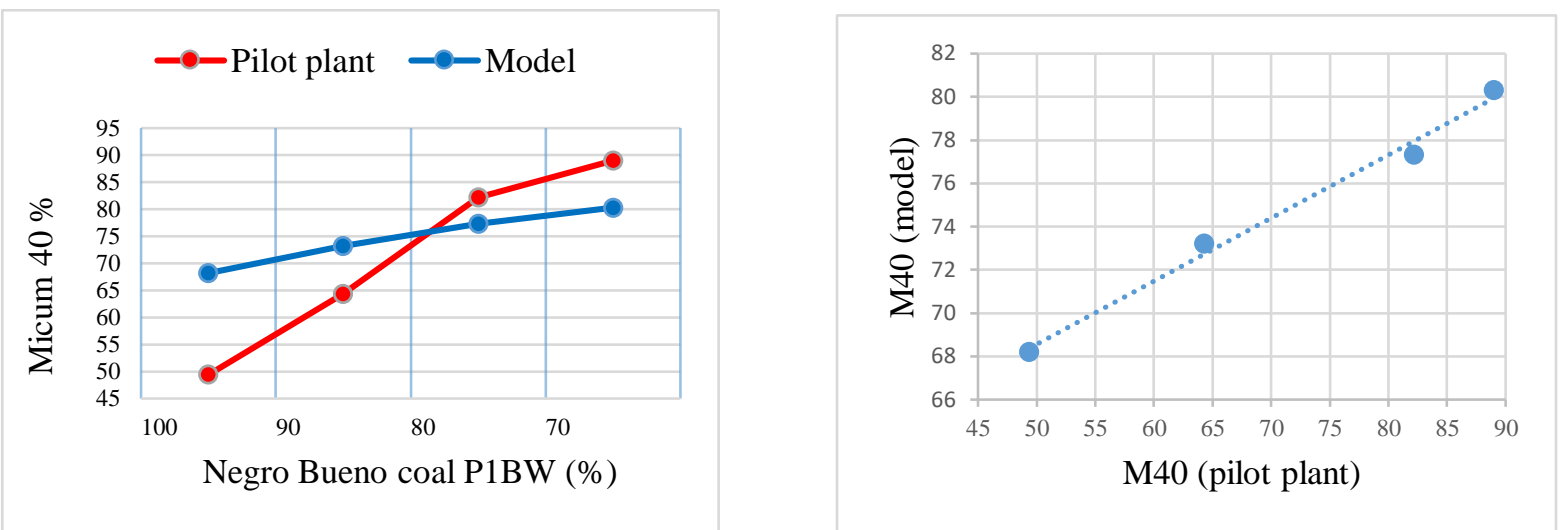

Figure 7. Blends of washed Negro Bueno coal (seam B) and Colombian C3 coal. Left: calculated and tested Micum 40 results. Right: correlation between calculation and test results.
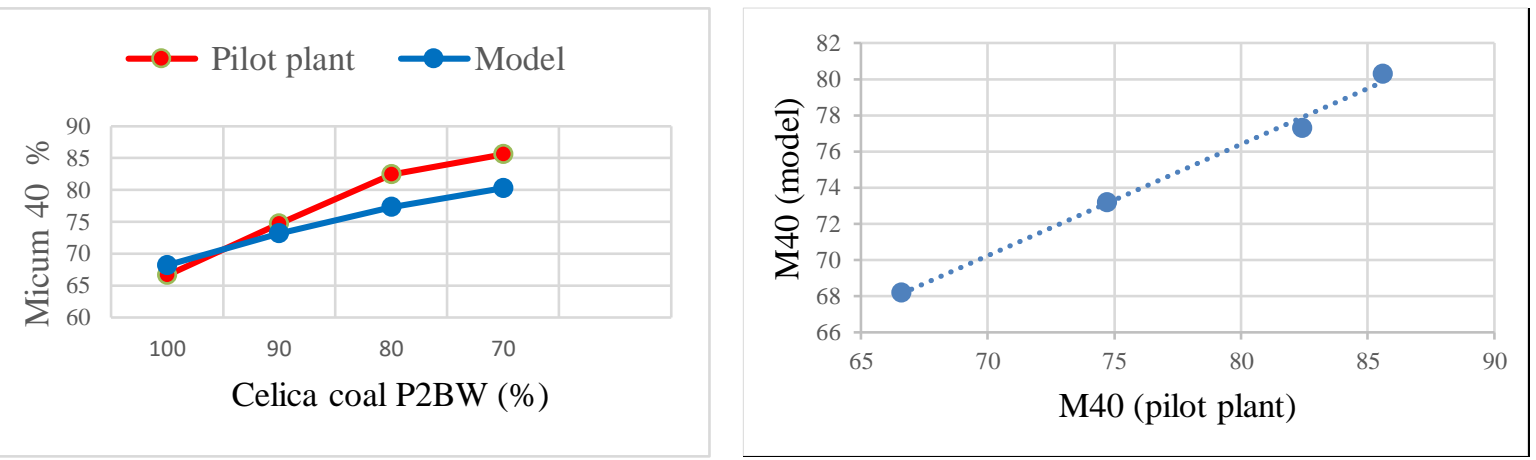

Figure 8. Blends of washed Celica coal (seam B) and Colombian C3 coal. Left: calculated and tested Micum 40 results. Right: correlation between calculation and test results.

\section{CONCLUSIONS}

The use of non-washed domestic coals must be discarded, as well as the use Oyon and Cachi-Cachi coals. Blends with large share of domestic coals, fulfilling the predefined quality aims, were obtained.

The blends with largest share of washed domestic coal that achieved the quality aim had $80 \%$ Negro Bueno coal (seam B, washed) or Celica coal, seam B, washed), and $20 \%$ of Colombian coal C3.

The required coke quality was also obtained for a blend with $30 \%$ of washed Cosmos coal, from Jatunhuasi basin, and $70 \%$ of Colombian coal C3. This result may improve with another imported coal and/or use of additives.

Anthracite could be used up to $10 \%$ in blend with $60 \%$ washed Celica coal of seam B and $30 \%$ of Colombian coal C2, increasing total coke yield and decreasing sulphur content. This result may be improved, too.

Acknowledgements. The authors are grateful to the management of Corporación Aceros Arequipa for permission to publish this paper. They appreciate the efforts of Engineers and Technicians that move forward the installation and start-up of the pilot plant, as well as those participating in the tests. 


\section{REFERENCES}

1. de Cordova, M.; Madias, J. "Coke quality for a mini blast furnace". metallon report, June 2010 (in Spanish)

2. Madias, J.; Colombo, L.; Ruiz, O.; "Correlation between a pilot oven and industrial coking batteries". Siderurgia No. 42, June 1986, pp. 34-42 (in Spanish).

3. Carrascal, R.; Matos, C.; Silva, O.; "Coal in Peru". National Engineering University, Geological, Mining and Metallurgy Institute INGMMET, Bulletin $\mathrm{N}^{\circ} 7$, Series B, Lima, Peru, October 2000, pp. 1-150 (in Spanish).

4. Curran, M.D.; "Report on coke elaborated with Oyon coal". INGMMET Technical Archive, Code A2282, July 1999 (in Spanish).

5. Ampuero, L.; "The coal industry in Peru, historic evolution and development perspectives", December 1969 (in Spanish).

6. The Peruvian, Official Journal, Lima, Peru, September 28, 1971 (in Spanish).

7. Paredes, R.; Baca, M.; "Pre-feasibility of the installation of a power station with anthracite gasification in La Libertad department - Peru" (in Spanish).

8. León, E.; "The importance of mineral coal in the development". Journal of the Research Institute of FIGMMG at UNMSM, Vol. $9 \mathrm{~N}^{\circ} 16,2006$, pp. 91-97 (in Spanish).

9. Vander T., "Negro Bueno Report Coal Analysis - Phase 1" Document N ${ }^{\circ}$ C0096/01, November 14, 2008, Revision A, IJmuiden, The Netherlands.

10. Madias, J.; de Cordova, M.; "A review on stamped charging of coals". AIST 2013 Proceedings, pp. 253-262.

11. de Córdova, M.; Madias, J.; "Review on modeling of coal blends for prediction of coke quality". AISTech 2016 Proceedings, pp. 297-309. 